\title{
Analysis of the performance measurement process of a 3PL provider: the case of a multinational company
}

\section{Análise do processo de medição de desempenho de um operador logístico: o caso de uma empresa multinacional}

\author{
Caroline Nascimento da Silva Cândido ${ }^{1}$ [ , Luis Felipe Cândido ${ }^{2}$ (ㄷ) \\ Sergio Henrique de Oliveira Lima ${ }^{3}$ (1) \\ 1Universidade Estácio de Sá - UNESA, Fortaleza, CE, Brasil. E-mail: carolinencandido@gmail.com \\ ${ }^{2}$ Universidade Federal do Ceará - UFC, Crateús, CE, Brasil. E-mail: luisfcandido2015@gmail.com \\ ${ }^{3}$ Universidade Federal do Cariri - UFCA, Juazeiro, CE, Brasil. E-mail: shlima05@gmail.com
}

How to cite: Cândido, C. N., Cândido, L. F., \& Lima, S. H. O. (2021). Analysis of the performance measurement process of a 3PL provider: the case of a multinational company. Gestão \& Produção, 28(4), e5604. https://doi.org/10.1590/1806-9649-2021v28e5604

\begin{abstract}
Performance measurement is considered a critical strategic process for companies operating in the logistics sector, as they need to perform high service levels under conditions of uncertainty. In this context, the present study aimed to evaluate the process of performance measurement in a multinational 3PL provider with a subsidiary in Fortaleza, Ceará. 31 indicators used by the company were identified and described, and its process of performance measurement was mapped. It was found that the company does not have a clear and well-structured process for performance measurement, which can lead to misinterpretations and management failures. In addition, the decision-making process proved to be mostly centered on the individual experience of employees, who might make decisions not aligned with the organizational objectives. The study discusses some manners to improve the process of performance measurement in the case investigated and proposes opportunities for further research in the field.
\end{abstract}

Keywords: Performance measurement; Operations management; Performance indicators; Third-party logistics.

Resumo: A medição de desempenho é considerada um processo estratégico crítico nas empresas que atuam no setor logístico, pois elas precisam desempenhar elevados níveis de serviço atuando sob condições de incerteza. Neste contexto, o presente estudo pretendeu analisar o processo de medição de desempenho em um operador logístico multinacional com filial em Fortaleza, Ceará. Foram identificados e descritos 31 indicadores utilizados pela empresa, cujo processo de medição de desempenho foi mapeado. Constatou-se que a empresa não possui um processo claro e bem estruturado para a medição de desempenho, o que pode gerar desvios de interpretação e falhas no gerenciamento. Além disso, o processo de tomada de decisão se mostrou predominantemente centralizado na experiência individual dos colaboradores, que podem tomar decisões desalinhadas dos objetivos organizacionais. $\mathrm{O}$ estudo discute algumas propostas para melhoria do processo de medição de desempenho no caso investigado e sugere oportunidades para futuras pesquisas no campo.

Palavras-chave: Medição de desempenho; Gestão de operações; Indicadores de desempenho; Prestadores de serviços logísticos.

Received July 17, 2019 - Accepted Oct. 11, 2020

Financial support: None.

This is an Open Access article distributed under the terms of the Creative Commons Attribution License, which permits unrestricted use, distribution, and reproduction in any medium, provided the original work is properly cited. 


\section{Introduction}

Outsourcing logistics operations is a global trend (Abidi et al., 2019; Chen \& Wu, 2011), as it enables savings by eliminating logistics costs relating to warehouses, trucks, and sorting equipment (Bolumole, 2003), allowing companies to focus on their essential skills (Oliveira et al., 2013).

This evolution is in line with changes in the business scenario, which have required greater managerial flexibility and dynamism (Fernandez et al., 2008; Zago et al., 2008), in light of the rapid technological development that has increased competition at the global level and eliminated physical barriers on the market (Bolumole, 2003). Other characteristic of this phenomenon are the increase in the complexity of supply chains (Chaves \& Callado, 2014) and the change in the nature of work and means of production (Bititci et al., 2012).

In this context, Third-Party Logistics (3PL) Providers should be seen not as mere service providers, but also as strategic partners (Zacharia et al., 2011), which makes it essential to have well-defined performance criteria that are continuously monitored through performance measurement.

This topic has been the subject of several studies carried out at the international level (Abidi et al., 2019; Bolumole, 2003; Chen \& Wu, 2011) and in Brazil (Abijaude et al., 2016; Longaray et al., 2015; Rodriguez et al., 2016; Zamcopé et al., 2010), which preserve, as a common feature, the emphasis on the study of performance measurement processes and their indicators.

Nevertheless, there is evidence that this process is poorly structured and lacks a systematic approach in the logistics sector (Beaulieu et al., 2018; Zago et al., 2008). This is also observed in other economic sectors, such as construction (Cândido et al., 2016), tourism (Sainaghi et al., 2017), digital marketing (Järvinen \& Karjaluoto, 2015), and even the public sector (Schwartz \& Deber, 2016). According to Cândido et al. (2016), performance measurement is a cyclical process that involves both performance measurement itself and performance management. Therefore, this process will be effective insofar as it allows management - decision making - to continuously improve this performance.

Thus, the knowledge gap explored in this research is evident: the lack of a structure relating to the measurement process and, subsequently, the decrease in the effectiveness of performance management. This gap has led to the following research question: How does performance measurement and management process in $3 \mathrm{PL}$ Providers occur?

In this sense, the purpose of this study was to assess the performance measurement process in operations management in 3PL Providers based on a case study carried out in a multinational company with a branch in Fortaleza, the capital of the state of Ceará, Brazil. Specifically, the study sought to characterize the indicators used by the company and describe the performance measurement process.

It is worthy to note that, unlike other studies in the transportation and logistics sector related to the measurement topic, such as Araújo et al. (2015), the present work does not focus solely on indicators, but rather on the measurement process itself. It sought to understand how the indicators used by the studied company support the management of its performance, which provided contributions to the understanding of the topic in the sector, as well as to improve the process of the company itself. 


\section{Theoretical background}

The measurement process involves issues that are specific to each organization and branch of activity (Zago et al., 2008). Thus, the theoretical background of the work sought to establish the main concepts of performance measurement, connecting them with the transportation and logistics sector, particularly the Third-Party Logistics service.

\subsection{Performance measurement}

As previously mentioned, performance measurement is a cyclical process, which involves measuring performance and managing the performance itself (Cândido et al., 2016). A number of performance measurement models exist in the literature, each of which has its own structure relating to organization, operation, and even taxonomy (Sink \& Tuttle, 1993).

This dispersion of models may cause misunderstandings in the design and use of a Performance Measurement System (PMS) (Cândido et al., 2016), constituting an initial difficulty for the establishment of an adequate process. In this sense, it is valid to understand the essential components of a PMS, as proposed by Franco-Santos et al. (2007):

- Characteristics: (i) having performance indicators; (ii) having an established support infrastructure;

- $\quad$ Roles: (i) measuring performance; (ii) managing the strategy; (iii) communicating results; (iv) influencing behavior; (v) providing learning and improvement;

- $\quad$ Processes: (i) defining and selecting indicators; (ii) collecting and processing data; (iii) managing information; (iv) evaluating and rewarding; (v) reviewing the system.

According to Franco-Santos et al. (2007), the elementary characteristic of a performance measurement system is having performance indicators. In fact, a measurement system is composed of a set of individual and connected performance indicators (Neely et al., 1995) that can be understood as any device that measures or records and provides indications relating to the processes and results of an organization (Sink \& Tuttle, 1993).

In addition to having an indicator, according to Franco-Santos et al. (2007), the second elementary characteristic is having a support infrastructure. This infrastructure may range from a simple method for data collection and analysis (e.g. use of spreadsheets) to a specialized and sophisticated information system, developed especially for this function (Cândido et al., 2016).

Thus, when based on a structured process, a measurement system is able to fulfill the roles of (i) measuring performance; (ii) managing the strategy; (iii) communicating the results; (iv) influencing behavior; (v) and providing learning and improvement (Franco-Santos et al., 2007). The more structured the system is, the more roles it is able to play, thereby assisting in performance management.

As the measurement process investigated in the research reported here followed this conceptual structure, it is necessary to deepen its "Processes" component. The first process - selection and definition of performance indicators - is developed in two stages: first, the decision of "what to measure," which should take place through a collaborative process between the company's managers, who must reach a consensus 
about the organization's objectives (Kaplan \& Norton, 1996; Neely et al., 2000) and about what "[...] criteria, measures, attributes and indicators must be monitored by the management team [...], on a periodic basis, in order to determine whether the strategic dimensions of performance are being achieved" (Sink \& Tuttle, 1993, p. 246). Second, the selection and definition are related to the presentation structure of these indicators, i.e., the information that is necessary for understanding and using each indicator.

There are several structures for the design of performance indicators. For example, Kaplan \& Norton $(1992,1996)$ employ a structure that demands the definition of (i) title; (ii) strategic goal to which the measure is linked; (iii) targets; (iv) initiatives; and (v) team or person in charge of the process. Neely et al. (1997), in turn, proposed a structure composed of fourteen items: (i) title; (ii) purpose of the measure; (iii) relationship with the goals; (iv) target of the indicator; (v) calculation formula; (vi) measurement frequency; (vii) frequency of the review; (viii) person in charge of the collection; (ix) source of the data; (x) manager; (xi) what the manager should do; (xii) who acts on the results; (xiii) what they should do (for those who act on the results); and (xiv) observations and comments. Finally, Medori \& Steeple (2000) propose that the following should be observed in the definition of the indicators: (i) title; (ii) goal; (iii) benchmarking; (iv) calculation formula; (v) measurement frequency; (vi) source of the data; (vii) responsibility; and (viii) improvement.

Regardless of the structure adopted, each of them provides an additional benefit: the institutionalization of the company's tacit knowledge. As the processes, indicators and goals are documented, the dissemination of organizational knowledge to all company structures is facilitated (Flapper et al., 2006). Among the analyzed proposals, the one presented by Neely et al. (1997) appears to be the one that best organizes the indicators and their definitions, being thus adopted to guide the present work.

The stage of data collection and processing focuses on how the necessary data should be collected and how it should be transformed into information, encompassing the form of storage and retrieval (Sousa et al., 2018). It is strongly linked to the use of information technology (IT), which makes it possible to improve tools and increase their reliability (Kennerley \& Neely, 2002).

Information management, in turn, is related to the ability to promote information flow (Sousa et al., 2018), either through its presentation form (considering the user of the information) or through the selection of the important information for each user (Cândido et al., 2016).

The use of PMS can have positive and negative impacts on people's attitudes (Franco-Santos et al., 2012; Lampreia \& Major, 2017) depending on how the evaluation is carried out and whether or not this evaluation is associated with a reward system (Franco-Santos et al., 2007). Thus, the evaluation and award stage involves criteria for evaluating the performance itself and justifying (or not) the granting of rewards. In other words, it aims to verify the parameters established for performance and enable the necessary decision making (Armstrong \& Brown, 2009; Safari, 2016).

Finally, the systematic review concerns the ability of the PMS to adapt to changing market scenarios, whether in terms of replacing indicators or targets (if the indicators still reflect organizational goals) or in terms of assessing the cost-benefit ratio of the measurement system itself. In other words, it reviews whether it is still acceptable in terms of its usefulness, efficiency, and consistency (Cândido et al., 2016).

The consolidation of these characteristics, roles and processes in performance measurement enables companies to perform performance management. In view of the recognized difficulty in understanding the structuring of a measurement system 
(Okwir et al., 2018; Toni \& Tonchia, 2001), there is no universal definition or structuring of what constitutes performance measurement (Choong, 2013).

In this specific matter, performance measurement and management must be understood as separate and interrelated concepts (Okwir et al., 2018), in order to create a more comprehensive and cyclical management process that truly creates the conditions for improving the efficiency of companies, according to the characteristics of the business and the sector in which it operates.

\subsection{Performance measurement in 3PL providers}

A 3PL Provider can be conceptualized as an agent with the ability to perform three basic activities (Oliveira et al., 2013): inventory control, storage, and transportation management. In this sense, Oliveira (2008) suggests that the integration of a 3PL Provider in a company takes place at different levels and on different links in the supply chain, fundamentally in storage and distribution. In order to achieve success in this partnership, the $3 \mathrm{PL}$ Provider must be strategically integrated into the company, employing the appropriate tools for performance evaluation and measurement (Luna, 2001), as the strategies must be aligned and well defined (Belmonte \& Botter, 2015) in addition to being verifiable through performance indicators (Neves, 2009).

A performance indicator can be understood as an instrument that assists managers in the management of their organizations (Sink \& Tuttle, 1993). The indicator comprises the basic unit and the central point of a Performance Measurement System (Neely et al., 1995), providing awareness of the company's performance and an alignment of actions at all hierarchical levels in pursuit of the established goals (Neves, 2009).

This proposition is relevant in the context of logistics. As argued by Bowersox et al. (2016), ultimately, logistical performance aims to increase shareholder value generation. According to these authors, performance indicators have three fundamental roles: monitoring, controlling, and directing logistics operations. Thus, as Ballou (2006) asserts, the basic premise of logistical performance is to embed order processing, the accuracy of order documentation, transportation, availability of products in stock, damaged products, production processing time, and production time storage.

In turn, Santos et al. (2009) list the following as performance requirements: the ability to make the product available, consistency in delivery time, physical delivery without damage to the product, flexibility to meet differentiated product requirements, speed of delivery and availability of information for follow-up. In the view of Chopra \& Meindl (2016), in order to measure logistical performance, its key factors must be emphasized: facilities, inventory, transportation, outsourcing, and pricing. Finally, Bowersox et al. (2016) highlight costs, customer services, quality requirements, productivity, and asset management.

It is clear that the various authors and studies addressed recommend indicators for different performance dimensions, which is corroborated by the empirical evidence: companies that use balanced indicators are more profitable compared to those whose performance is based exclusively on financial metrics (Rocha et al., 2012).

In this sense, in addition to the performance dimension (cost, term, quality, and so on), performance indicators can be classified according to their link with the business stages. Thus, there are input indicators, process indicators, and output - or results indicators (Neves, 2009), as shown in Figure 1. 


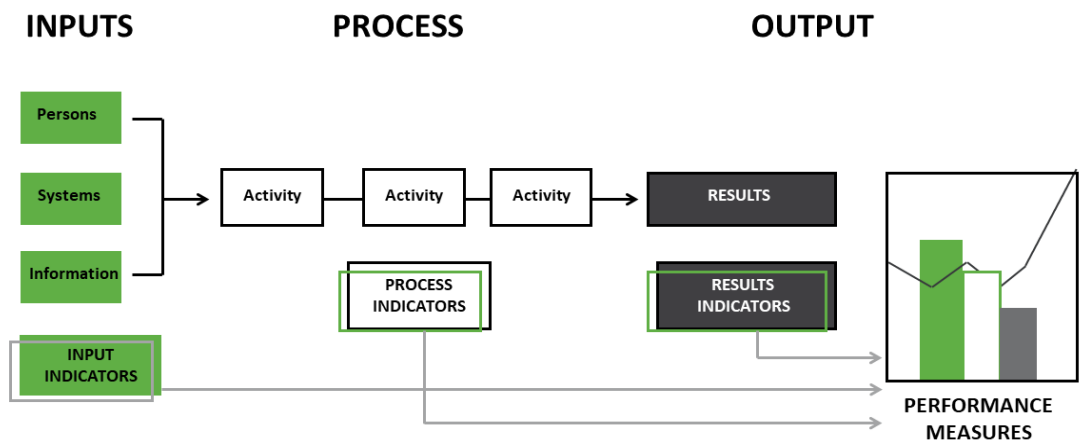

Figure 1. Types of performance indicators. Source: adapted from Neves (2009).

Once an indicator is defined, a number of logistical dimensions must be included, as well as their relationship with the generic stages of a business process. The study sought to identify examples of logistical indicators in the literature. It started from the classic propositions of Ballou (2006), Bowersox et al. (2016) and Chopra \& Meindl (2016), adding the works presented in Table 1 and discussed below. In all, 164 different indicators were identified.

When grouped according to the key logistical factors of Chopra \& Meindl (2016), it appears that $48(29 \%)$ refer to facilities, $29(18 \%)$ to information, $28(17 \%)$ to transportation, $22(13 \%)$ to inventory, $20(12 \%)$ to price, and $17(10 \%)$ to contracting third parties. In a second analysis, the indicators were classified according to their link with the process step (input, processing, or output). There is a predominance of indicators related to the process $(74 \%)$, followed by input $(22 \%)$ and output $(4 \%)$ indicators. It should also be noted that the most recurrent indicator identified Deliveries made on time - is considered by Neves (2009) as the most widely measured indicator in logistical contracts and shows the percentage of deliveries (or collections) made in the term provided in the contract.

Of the 164 indicators, only 27 showed a recurrence in more than one study, as highlighted in Table 1.

Table 1. Most recurrent logistics performance indicators in the literature.

\begin{tabular}{|c|c|c|c|c|c|c|c|c|c|c|c|c|}
\hline $\begin{array}{l}\text { Indicator I } \\
\text { Author }\end{array}$ & A & B & C & D & $\mathbf{E}$ & $\mathbf{F}$ & G & $\mathbf{H}$ & I & $\mathbf{J}$ & Freq. & $\%$ \\
\hline $\begin{array}{c}\text { Deliveries } \\
\text { made on time }\end{array}$ & $x$ & $x$ & & $x$ & & & $x$ & $x$ & & $x$ & 6 & $70 \%$ \\
\hline Perfect order & & $x$ & & $x$ & & $x$ & $x$ & & & $x$ & 5 & $50 \%$ \\
\hline $\begin{array}{c}\text { Order } \\
\text { fulfillment } \\
\text { index }\end{array}$ & $x$ & $x$ & & $x$ & & & & $x$ & $x$ & & 5 & $50 \%$ \\
\hline $\begin{array}{l}\text { Inventory } \\
\text { turnover }\end{array}$ & $x$ & & & $x$ & & & & $x$ & $x$ & & 4 & $40 \%$ \\
\hline Fault index & $x$ & & $x$ & $x$ & & & $x$ & & & & 4 & $40 \%$ \\
\hline $\begin{array}{l}\text { Use of truck } \\
\text { load capacity }\end{array}$ & & & $x$ & $x$ & & $x$ & & & $x$ & & 4 & $40 \%$ \\
\hline $\begin{array}{l}\text { Use of storage } \\
\text { capacity }\end{array}$ & & & $x$ & $x$ & & & & & $x$ & & 3 & $30 \%$ \\
\hline $\begin{array}{l}\text { Lack of } \\
\text { inventory }\end{array}$ & $x$ & $x$ & & & & & & $x$ & & & 3 & $30 \%$ \\
\hline
\end{tabular}


Table 1. Continued...

\begin{tabular}{|c|c|c|c|c|c|c|c|c|c|c|c|c|}
\hline $\begin{array}{c}\text { Indicator / } \\
\text { Author }\end{array}$ & A & B & C & D & $E$ & $\mathbf{F}$ & G & $\mathbf{H}$ & I & $\mathbf{J}$ & Freq. & $\%$ \\
\hline $\begin{array}{c}\text { Total logistical } \\
\text { cost }\end{array}$ & & & & & & $x$ & $x$ & $x$ & & & 3 & $30 \%$ \\
\hline $\begin{array}{c}\text { Transportation } \\
\text { cost }\end{array}$ & $x$ & & & & & $x$ & $x$ & & & & 3 & $30 \%$ \\
\hline $\begin{array}{l}\text { Order cycle } \\
\text { time }\end{array}$ & & & & $x$ & & $x$ & & $x$ & & & 3 & $30 \%$ \\
\hline $\begin{array}{c}\text { Documentation } \\
\text { accuracy }\end{array}$ & & $x$ & & & & & & $x$ & & & 2 & $20 \%$ \\
\hline $\begin{array}{l}\text { Steering } \\
\text { accuracy }\end{array}$ & & & & $x$ & & & & $x$ & & & 2 & $20 \%$ \\
\hline $\begin{array}{l}\text { Information } \\
\text { accuracy }\end{array}$ & & & & & & & & $x$ & $x$ & & 2 & $20 \%$ \\
\hline $\begin{array}{l}\text { Availability of } \\
\text { information }\end{array}$ & & & & & & & & $x$ & & $x$ & 2 & $20 \%$ \\
\hline $\begin{array}{l}\text { Inventory } \\
\text { balancing } \\
\text { according to } \\
\text { the } \mathrm{ABC} \text { curve }\end{array}$ & & & & $x$ & & & & $x$ & & & 2 & $20 \%$ \\
\hline $\begin{array}{l}\text { Inventory } \\
\text { coverage }\end{array}$ & & & & $x$ & & & & $x$ & & & 2 & $20 \%$ \\
\hline $\begin{array}{l}\text { Obsolete } \\
\text { inventory }\end{array}$ & & & & & & & & $x$ & $x$ & & 2 & $20 \%$ \\
\hline $\begin{array}{l}\text { Cost of non- } \\
\text { conformities in } \\
\text { Transportation }\end{array}$ & & & & $x$ & & & & $x$ & & & 2 & $20 \%$ \\
\hline $\begin{array}{l}\text { Inventory and } \\
\text { storage cost }\end{array}$ & $x$ & & & & & & $x$ & & & & 2 & $20 \%$ \\
\hline $\begin{array}{l}\text { Return cost as } \\
\text { a percentage } \\
\text { of the cost of } \\
\text { goods sold } \\
\text { (COGS) }\end{array}$ & & $x$ & & $x$ & & & & & & & 2 & $20 \%$ \\
\hline $\begin{array}{c}\text { Deliveries } \\
\text { returned in } \\
\text { whole or in } \\
\text { part }\end{array}$ & $x$ & & & & & & & & & $x$ & 2 & $20 \%$ \\
\hline $\begin{array}{l}\text { Complete } \\
\text { orders }\end{array}$ & & & & & & & & $x$ & & $x$ & 2 & $20 \%$ \\
\hline $\begin{array}{l}\text { Percentage of } \\
\text { immediate } \\
\text { deliveries }\end{array}$ & & $x$ & & & & & & & $x$ & & 2 & $20 \%$ \\
\hline Backorders & & $x$ & & & & & & $x$ & & & 2 & $20 \%$ \\
\hline $\begin{array}{l}\text { Dock-to-stock } \\
\text { time }\end{array}$ & & & $x$ & $x$ & & & & & & & 2 & $20 \%$ \\
\hline $\begin{array}{c}\text { Complaint } \\
\text { response time }\end{array}$ & & & & & & & $x$ & $x$ & & & 2 & $20 \%$ \\
\hline
\end{tabular}

Note: (A) Conceição \& Quintão (2004), (B) Ballou (2006), (C) Fernandez et al. (2008), (D) Neves (2009), (E) Araújo et al. (2015), (F) Belmonte \& Botter (2015), (G) Longaray et al. (2015), (H) Bowersox et al. (2016), (I) Chopra \& Meindl (2016), and (J) Vieira et al. (2016). Source: the authors.

Nevertheless, having performance indicators is only the initial step in a measurement process, as discussed earlier. The simple use of a performance indicator 
does not guarantee the company's success (Franco-Santos et al., 2012; Neely \& Bourne, 2000), but also the ability of managers and employees to interpret the results and, based on them, promote change (Franco-Santos et al., 2012).

It is in this specific aspect that this study is inserted. There is evidence that this process is poorly structured and lacks a structured approach in the logistics sector (Beaulieu et al., 2018; Zago et al., 2008), which makes performance management unfeasible. The measurement process is explored here based on the characteristics, roles and processes defined by Franco-Santos et al. (2007), as previously discussed.

\section{Research method}

This research consists of a case study - a strategy whose goal is to investigate a contemporary phenomenon within its real context (Yin, 2010). The case study was descriptive, as it sought to evaluate and describe the characteristics of the studied phenomenon (Collis \& Hussey, 2005) with a qualitative approach - advocating the "how" and "why" (Cooper \& Schindler, 2016).

The study was carried out at a branch of a multinational 3PL Provider, hereinafter referred to as Alpha Company. The company has been operating in the Brazilian market since 1942 and was incorporated, in 2012, by a multinational that operates on all continents, providing its logistics and cargo transportation services in the air and road modes, in the B2B (business-to-business) and B2C (business-to-customer) segments. It should be noted that the study focused on the sectors of operations, as highlighted in Figure 2.

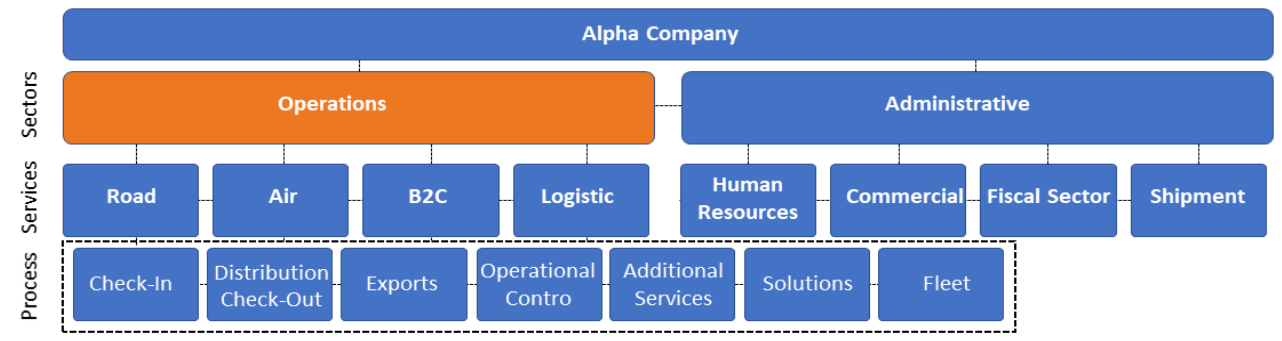

Figure 2. Organizational structure of the subsidiary of Alpha Company.

The data were collected through in-depth interviews, participant observation, and document collection. The in-depth interview was conducted using a semi-structured script, as it was desired to form the knowledge from the interviewee's point of view, without imposing the interviewer's view (Gray, 2012; Richardson, 2011). Open questions were used, according to the subject presented in Table 2.

Table 2. Characterization of the interview script.

\begin{tabular}{lcl}
\multicolumn{1}{c}{ Part } & $\begin{array}{l}\text { Number of } \\
\text { Questions }\end{array}$ & \multicolumn{1}{c}{ Description } \\
\hline $\begin{array}{l}\text { I- Characterization of } \\
\text { the interviewee and the } \\
\text { company }\end{array}$ & 03 & $\begin{array}{l}\text { Information about the company with regard to } \\
\text { market positioning, management philosophy, } \\
\text { size, and characteristics that influence its } \\
\text { performance measurement system. }\end{array}$ \\
\hline
\end{tabular}


Table 2. Continued...

\begin{tabular}{lcl}
\multicolumn{1}{c}{ Part } & $\begin{array}{l}\text { Number of } \\
\text { Questions }\end{array}$ & Description \\
\hline $\begin{array}{l}\text { II - Characterization of } \\
\text { the performance } \\
\text { measurement process in } \\
\text { the company }\end{array}$ & 12 & $\begin{array}{l}\text { Its goal is to survey, in general, what is done } \\
\text { and carry out a self-criticism about the system, } \\
\text { through questions about the processes. }\end{array}$ \\
\hline
\end{tabular}

With this script, six interviews were conducted with the subjects featured in Table 3.

Table 3. Characterization of the respondents from Alpha Company.

\begin{tabular}{|c|c|c|c|c|}
\hline \multirow{2}{*}{ Interviewee } & \multirow{2}{*}{ Title } & \multirow{2}{*}{ Process } & \multicolumn{2}{|c|}{ Seniority } \\
\hline & & & Company & Title \\
\hline$A$ & $\begin{array}{l}\text { Operations } \\
\text { Foreman }\end{array}$ & $\begin{array}{c}\text { Distribution Check- } \\
\text { Out }\end{array}$ & 8 years & 1.5 year \\
\hline B & $\begin{array}{l}\text { Operations } \\
\text { Foreman }\end{array}$ & $\begin{array}{l}\text { Operational } \\
\text { Control }\end{array}$ & 9 years & 2 years \\
\hline C & $\begin{array}{l}\text { Operations } \\
\text { Foreman }\end{array}$ & Solution & 10 years & 2 months \\
\hline D & $\begin{array}{c}\text { Operations } \\
\text { Foreman }\end{array}$ & $\begin{array}{c}\text { General - Air } \\
\text { Mode }\end{array}$ & 14 years & 5 years \\
\hline$E$ & $\begin{array}{l}\text { Operations } \\
\text { Supervisor }\end{array}$ & B2C & 11 years & 4 years \\
\hline $\mathrm{F}$ & $\begin{array}{l}\text { Operations } \\
\text { Supervisor }\end{array}$ & Exports & 23 years & 20 years \\
\hline
\end{tabular}

Based on the interviews, documents were collected in the form of spreadsheets containing indicators and performance reports in order to complement the interviews, according to the characterization presented in Table 4. Although it is a type of evidence not mastered by the researcher, documentary sources allow the mitigation of his subjective influence on the subject and, consequently, on the analysis of the phenomenon (Cellard, 2010).

Table 4. Characterization of the collected documents.

\begin{tabular}{cccc}
\hline Code & Document & Sector & Source \\
\hline D001 & $\begin{array}{c}\text { Presentation of the general } \\
\text { management meeting }\end{array}$ & General & Alpha Company database \\
\hline D002 & Indicator management & Operational Control & Operations Foreman \\
D003 & $\begin{array}{c}\text { Perfect delivery indicator } \\
\text { report }\end{array}$ & General & Alpha Company database \\
\hline D004 & $\begin{array}{c}\text { Presentation of the board } \\
\text { meeting }\end{array}$ & Exports & Operations Foreman \\
D005 & $\begin{array}{c}\text { Presentation of the board } \\
\text { meeting }\end{array}$ & Air & Operations Foreman \\
\hline D006 & $\begin{array}{c}\text { Standard Operating } \\
\text { Procedure (SOP) }\end{array}$ & Air & Alpha Company database \\
\hline D007 & $\begin{array}{c}\text { Dashboards - Occurrence } \\
\text { Indicator Management }\end{array}$ & Solution & Operations Foreman \\
\hline
\end{tabular}


Finally, a participant-type observation was performed (Creswell, 2007), as one of the researchers was inserted into the real context of the studied phenomenon. These observations were recorded using photographs and an observation journal. There was also participation in a "Follow-up Meeting" on the company's premises in which the indicators were discussed. This was held on July 21, 2017 and was attended by all those in charge of all processes, as well as the company's managers, which allowed us to understand the process of using the indicators in decision making.

The data analysis technique used in the study was content analysis (Chizzoti, 2011; Gibbs, 2009). It is a robust method for analyzing data from different sources of evidence, such as interview transcripts, documents, and observations notes (Labuschagne, 2003).

Through the triangulation of these different sources (Teixeira \& Nascimento, 2011), the study sought to provide greater validity and reliability to the research results (Barbosa, 2008), eliminating the possibility of typical biases of qualitative studies (Creswell, 2007). The results obtained from the content analysis and the triangulation of the research data are presented below.

\section{Results and discussions}

The presentation and discussion of the research findings were divided into three parts: (i) a characterization of Alpha Company's indicators; (ii) a description of Alpha Company's performance measurement process; and (iii) a summary of Alpha Company's performance measurement.

\subsection{Analysis of Alpha Company's PMS characteristics}

The analyzed company has 31 performance indicators that are related to processes and services, as shown in Table 5.

Table 5. Alpha Company's operational indicators

\begin{tabular}{|c|c|c|c|c|}
\hline No. & Indicator & Unit & Goal & Process / Service \\
\hline 1 & Effectiveness & $\%$ & $97.00 \%$ & $\mathrm{~B} 2 \mathrm{C}$ \\
\hline 2 & Perfect Delivery NSL (road) & $\%$ & $90.00 \%$ & $\begin{array}{c}\text { Distribution check-out } \\
\text { - Road }\end{array}$ \\
\hline 3 & Perfect Delivery NSL (air) & $\%$ & $94.00 \%$ & $\begin{array}{c}\text { Distribution check-out } \\
\text { - Air }\end{array}$ \\
\hline 4 & Scan compliance VAN & $\%$ & $96.00 \%$ & $\begin{array}{c}\text { Distribution check-out } \\
\text { - Air }\end{array}$ \\
\hline 5 & Scan compliance SIP / HIP & $\%$ & $96 \% / 65 \%$ & Check-in - Air \\
\hline 6 & $\begin{array}{c}\text { Scan compliance SOP / } \\
\text { HOP }\end{array}$ & $\%$ & $96 \% / 65 \%$ & Export - Air \\
\hline 7 & POD Scan X Goal & $\%$ & $90.00 \%$ & $\begin{array}{c}\text { Operational Control - } \\
\text { Air / B2C }\end{array}$ \\
\hline 8 & Requests & Hours & 4 & $\begin{array}{c}\text { Operational Control - } \\
\text { Road / Air }\end{array}$ \\
\hline 9 & Claims & Hours & 16 & $\begin{array}{c}\text { Operational Control - } \\
\text { Road / Air }\end{array}$ \\
\hline 10 & CTCs open (7 days) & $\%$ & $10 \%$ & $\begin{array}{c}\text { Operational Control - } \\
\text { Road / Air }\end{array}$ \\
\hline
\end{tabular}


Table 5. Continued...

\begin{tabular}{|c|c|c|c|c|}
\hline No. & Indicator & Unit & Goal & Process / Service \\
\hline 11 & $\begin{array}{l}\text { CTRCs usually open (of } \\
\text { merchandise) }\end{array}$ & $\mathrm{R} \$$ & No goal & $\begin{array}{l}\text { Operational Control - } \\
\text { Road / Air }\end{array}$ \\
\hline 12 & $\begin{array}{l}\text { Special Revenues - } \\
\text { Released (cumulative) }\end{array}$ & $\%$ & $85.00 \%$ & $\begin{array}{c}\text { Operational Control - } \\
\text { Road / Air }\end{array}$ \\
\hline 13 & Productivity / Efficiency & $\%$ & $94.00 \%$ & $\begin{array}{l}\text { Distribution check-out } \\
\text { - Road / Air }\end{array}$ \\
\hline 14 & Air Export Freight & $\%$ & $30.00 \%$ & Export - Air \\
\hline 15 & Road Export Freight & $\%$ & $20.00 \%$ & Export - Road \\
\hline 16 & Cost per volume (air) & $\mathrm{R} \$$ & $\mathrm{R} \$ 5.00$ & Export - Air \\
\hline 17 & Cost per volume (road) & $\mathrm{R} \$$ & $\mathrm{R} \$ 1.92$ & Export - Road \\
\hline 18 & Average cost per kg & $\mathrm{R} \$$ & $\mathrm{R} \$ 1.70$ & Export - Air \\
\hline 19 & Average cost per km & $\mathrm{R} \$$ & $\mathrm{R} \$ 3.76$ & Export - Road \\
\hline 20 & General delivery inefficiency & $\%$ & $6.00 \%$ & $\begin{array}{l}\text { Distribution check-out } \\
\text { - Air / Road }\end{array}$ \\
\hline 21 & $\begin{array}{l}\text { Delivery inefficiency - } \\
\text { Company Responsibility }\end{array}$ & $\%$ & $5.00 \%$ & $\begin{array}{c}\text { Distribution check-out } \\
- \text { Air / Road }\end{array}$ \\
\hline 22 & Scheduling Lost - General & $\%$ & $2.00 \%$ & $\begin{array}{l}\text { Operational Control - } \\
\text { Road }\end{array}$ \\
\hline 23 & $\begin{array}{c}\text { Scheduling Lost - Company } \\
\text { Responsibility }\end{array}$ & $\%$ & ZERO & $\begin{array}{l}\text { Operational Control - } \\
\text { Road }\end{array}$ \\
\hline 24 & $\begin{array}{l}\text { \% Electronic Bill of Lading } \\
\text { scanned }\end{array}$ & $\%$ & $88.96 \%$ & $\begin{array}{l}\text { Operational Control - } \\
\text { Air / Road / B2C }\end{array}$ \\
\hline 25 & $\begin{array}{l}\text { Scan time - CAP (up to } 2 \\
\text { days after delivery) }\end{array}$ & $\%$ & $90.00 \%$ & $\begin{array}{l}\text { Operational Control - } \\
\text { Air / Road / B2C }\end{array}$ \\
\hline 26 & $\begin{array}{c}\text { Scan time - ITN (up to } 7 \\
\text { days after delivery) }\end{array}$ & $\%$ & $80 \%$ & $\begin{array}{l}\text { Operational Control - } \\
\text { Air / Road / B2C }\end{array}$ \\
\hline 27 & $\begin{array}{c}\text { Time to resolve pending } \\
\text { issues }\end{array}$ & days & 3 & $\begin{array}{c}\text { Operational Control - } \\
\text { Road }\end{array}$ \\
\hline 28 & $\begin{array}{l}\text { Occurrences (failure and } \\
\text { fault) }\end{array}$ & $\%$ & $0.19 \%$ & $\begin{array}{c}\text { Solution - Air / Road / } \\
\text { B2C }\end{array}$ \\
\hline 29 & Indemnified / Invoicing & $\mathrm{R} \$$ & 0.25 & $\begin{array}{c}\text { Solution -Aerial / Road } \\
\text { / B2C }\end{array}$ \\
\hline 30 & $\begin{array}{l}\text { Indemnified / quantity of } \\
\text { handling volumes }\end{array}$ & $\%$ & $0.01 \%$ & $\begin{array}{l}\text { Solution - Aerial / } \\
\text { Road / B2C }\end{array}$ \\
\hline 31 & Balance sheet (inventory) & $\%$ & $98 \%$ & $\begin{array}{l}\text { Solution - Aerial / } \\
\text { Road / B2C }\end{array}$ \\
\hline
\end{tabular}

Among the services analyzed - related to the operation sector shown in Figure 2 (check-in, distribution check-out, exports, operational control, additional services, solutions, and fleet) - only the additional services do not have performance indicators in the company. When classified according to the functional areas of a logistical operation - following Chopra \& Meindl (2016) - 48\% of the indicators are related to facilities, $23 \%$ to contracting third parties, $19 \%$ to transportation, $6 \%$ to information, and $3 \%$ (only one) to the inventory. When indicators are classified according to their link with the process step (input, process, output), it is observed that 28 of the 31 indicators are related to the process, which was expected, as this present work aims to analyze logistic performance indicators related to operations management.

In this sense, in comparison with the main indicators raised in the literature, there is correspondence in the importance of the indicators related to the facilities. 
Furthermore, the role of measuring performance is highlighted, as proposed by FrancoSantos et al. (2007).

It was found that the Standard Operating Procedure (SOP) for the airline industry (Document D006) does not explain how to use the performance indicators, but rather merely mentions them, as shown in Figure 3. It is also noteworthy, according to observations and the presentation of the air sector steering meeting (Document D005), that not all indicators are in the SOP.

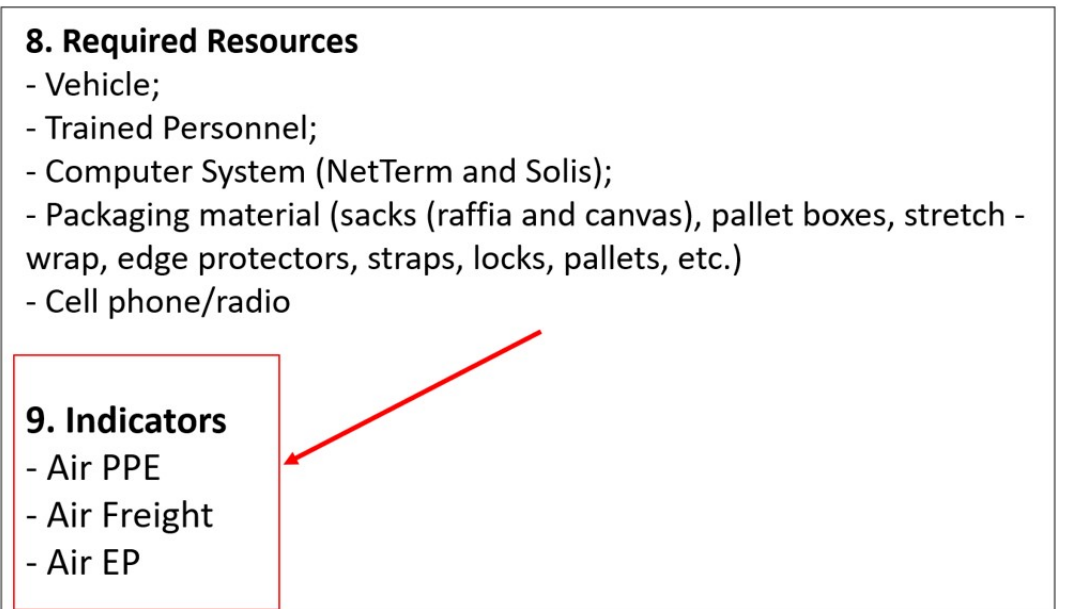

Figure 3. Section of the aerial SOP that mentions the indicators. Source: Document D006.

The interviewees were unanimous regarding the importance of the indicators for the management of operations, as shown in Table 6.

Table 6. Importance of indicators for the management of operations.

\begin{tabular}{|c|c|c|}
\hline Operations Foreman (A) & Operations Foreman (B) & Operations Foreman (C) \\
\hline $\begin{array}{l}\text { Yes, they are very } \\
\text { important [...]. Each sector } \\
\text { has this perfect delivery } \\
\text { indicator because it } \\
\text { measures the quality of our } \\
\text { service [...]. }\end{array}$ & $\begin{array}{l}\text { Yes, all indicators are } \\
\text { important because they } \\
\text { measure the quality of the } \\
\text { service level and guide the } \\
\text { operation towards achieving } \\
\text { the goals. }\end{array}$ & $\begin{array}{l}\text { Actually, these indicators work like } \\
\text { a thermometer. Through them, we } \\
\text { assess whether or not we are } \\
\text { doing well during the month and } \\
\text { which way we should go. }\end{array}$ \\
\hline Operations Foreman (D) & Operations Supervisor (E) & Operations Supervisor (F) \\
\hline $\begin{array}{l}\text { It is important to measure } \\
\text { our performance every day } \\
\text { [...], in the decision-making } \\
\text { process, in our operations } \\
\text { planning, to find out if the } \\
\text { resources are being used } \\
\text { properly [...]. }\end{array}$ & $\begin{array}{l}\text { So indicators become } \\
\text { important because of that ... } \\
\text { They show us day by day, in } \\
\text { detail, where we have a } \\
\text { problem and where we can } \\
\text { improve. }\end{array}$ & $\begin{array}{l}\text { They are important because they } \\
\text { allow the company hired to provide } \\
\text { the service to monitor its } \\
\text { performance and identify where it } \\
\text { can continuously improve. }\end{array}$ \\
\hline
\end{tabular}

In the perception of two out of those in charge of operations (participants A and B), this importance is reflected in the quality of the service provided to customers. In turn, in the view of Supervisors $E$ and $F$, it manifests itself in continuous improvement.

Table 7 shows how the use of indicators assists in the management of Alpha Company's operation. 
Table 7. Use of indicators in the management of Alpha Company's operations.

\begin{tabular}{|c|c|c|}
\hline Operations Foreman (A) & Operations Foreman (B) & Operations Foreman (C) \\
\hline $\begin{array}{l}\text { The work we perform here } \\
\text { is all based on indicators, } \\
\text { in order to achieve these } \\
\text { goals... all the decisions } \\
\text { that are made [...] aim at } \\
\text { achieving these results. }\end{array}$ & $\begin{array}{l}\text { Through them, we follow the } \\
\text { goals and performance and } \\
\text { identify where we should } \\
\text { employ more resources and } \\
\text { effort and what are the critical } \\
\text { issues that deserve more } \\
\text { attention in operations. }\end{array}$ & $\begin{array}{l}\text { [...] Each indicator works like a } \\
\text { thermometer, so when any of my } \\
\text { indicators are underperforming, I } \\
\text { can create action plans to } \\
\text { achieve the results. }\end{array}$ \\
\hline Operations Foreman (D) & Operations Supervisor (E) & Operations Supervisor (F) \\
\hline $\begin{array}{l}\text { The indicators assist in } \\
\text { guiding our daily } \\
\text { operations. They guide our } \\
\text { decision making, assisting } \\
\text { the team in the use of } \\
\text { resources. }\end{array}$ & $\begin{array}{l}\text { Through the daily monitoring, } \\
\text { we identify where we are failing, } \\
\text { either in delivery or in the } \\
\text { warehouse operation. }\end{array}$ & $\begin{array}{l}\text { Well, they essentially measure } \\
\text { customer satisfaction and my } \\
\text { performance in providing the } \\
\text { service. That is, they allow me to } \\
\text { provide good customer service } \\
\text { and monitor my team's day-by- } \\
\text { day performance. }\end{array}$ \\
\hline
\end{tabular}

It can be observed that the indicators are well inserted into the routine of the employees, its main role being to identify performance gaps. Nevertheless, not all employees understand the benefit of the indicators, as can be seen in the interview with Operations Foreman A, regarding the Productivity indicator (the respondent mentions that he does not know how to specifically explain the benefits of the indicator). This misunderstanding may be due to the lack of a manual of indicators or specific training on the use of indicators, which comprises an opportunity for improvement. Despite this, there is evidence of the use of indicators to manage the strategy, as proposed by Franco-Santos et al. (2007), at the level of operational routines. It was not possible to observe, however, if this is reflected in the most strategic levels of the company.

\subsection{Alpha Company's performance measurement process}

In this section, the results are addressed in light of the proposal by FrancoSantos et al. (2007) on the processes component of a PMS, as follows: of (i) defining and selecting indicators; (ii) collecting and processing the data; (iii) managing the information; (iv) evaluating and rewarding; and (v) reviewing the system. As regards the process of selection and definition of indicators, according to the document Management of Indicators (D002), the definition structure presents only the indicator, its measurement unit, and its goals. There are no fundamental items such as the formula for the indicator, person in charge of the indicator, etc., constituting a new opportunity for improvement.

For a measurement system, the formalization of processes is a key component (Toni \& Tonchia, 2001), in addition to allowing the institutionalization of the company's knowledge (Flapper et al., 2006). Thus, it would be interesting to formalize a manual of performance indicators, recommending the use of the model proposed by Neely et al. (1997), as it provides consistent subsidies for the correct use of a performance indicator.

All indicators, according to the interviews, are collected and processed via the system by those in charge of the processes. Thus, it is observed that the second process of performance measurement - data collection and processing - is automated. Operations Foreman D added that newsletters are sent (via email) with the result of the 
perfect delivery indicator of the most important customers, either due to the representativeness of invoicing or to the volume of deliveries.

In relation to information management, the indicators are presented on a weekly basis to the operations team at the Steering Meeting and to management at the meeting of indicators. During the observation of the participants, it was found that employees had difficulties in presenting (how to measure and disseminate results) and in analyzing the indicators, which was always questioned by the branch manager. The information is also disseminated through sight management panels, as shown in Figure 4.

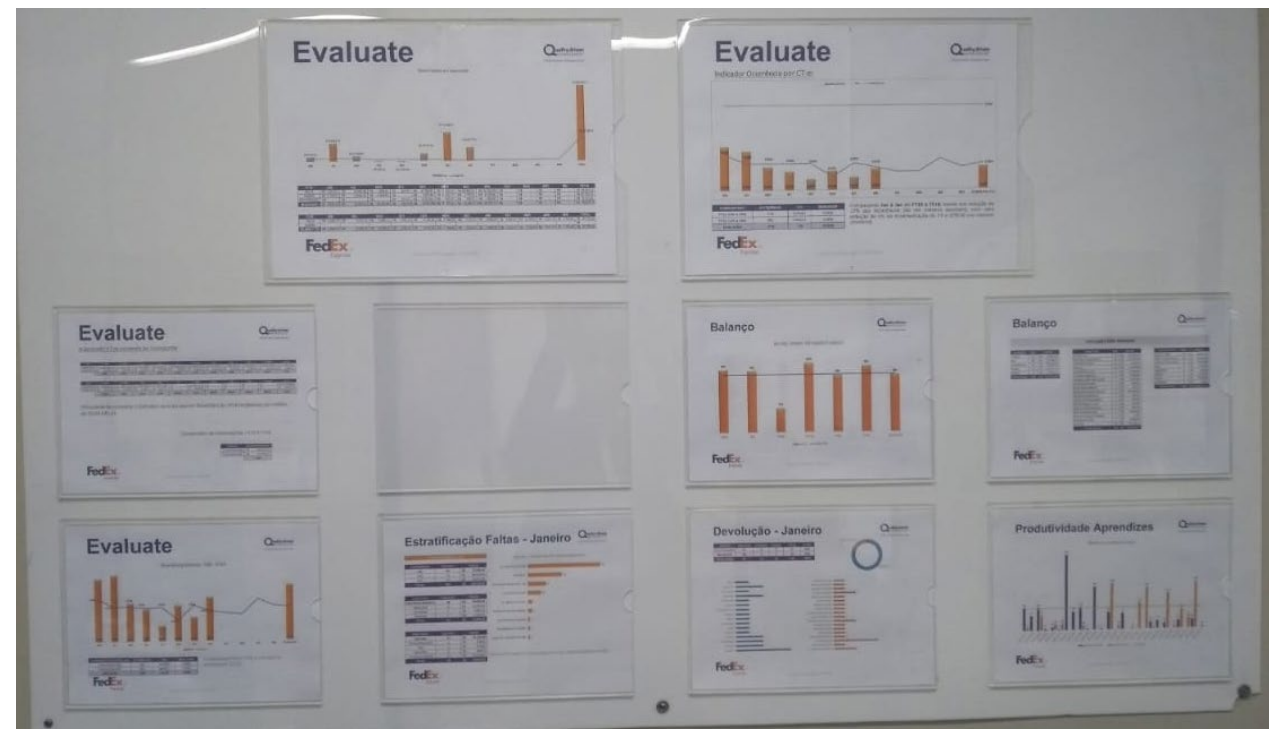

Figure 4. Example of a dashboard exposed in the "Solutions" sector room.

It should be noted that the indicators are also presented to employees at the operational level and that each of these dashboards contains information and methodologies that are appropriate to their target audiences. In the first case, the target audience operates at the managerial level, including supervisors and managers. In the second, the target audience operates at an operational level. Thus, the way results are presented must meet this audience, which has less demand for managerial information.

This is considered a good practice, as the dissemination of information on results influences the behavior of employees, motivating the work team (Lampreia \& Major, 2017). The use of indicators to communicate the results, as proposed by FrancoSantos et al. (2007), is also noteworthy. Nevertheless, it was not verified whether, and how, this is done for the external public, the process being restricted to internal stakeholders.

Another relevant point is the establishment of a measurement culture that supports management and avoids the feeling of punitive control (Sink \& Tuttle, 1993). This appears to be exactly what happens in the company, according to the Operations Foreman A, for whom there is no history of punishment:

There is no history of punishment. At least, I am not aware of any punishment for [somebody] who failed to achieve goals. As we follow-up the indicators weekly, we already have an assessment of what is going good and what is going bad, so no one is caught off guard at the end of each month [...]. 
This is true not only for company employees, but for the 3PL Provider as a whole. The contracts provide for liens and bonuses, as mentioned by the Operations Supervisor:

The contract lists both fines and bonuses [...]. We lose in terms of invoicing if we fail to reach an indicator, but we also get an additional percentage from the contract if we do reach the indicator established.

Thus, in relation to the fourth process - evaluation and award - it can be said that the only evaluation guideline is the indicator's target itself. This is insufficient, as it does not indicate what can be done with good or bad performance, but rather only the parameter to identify it. It was also found that employees do not receive bonuses for meeting these goals, although contracts provide for the payment of bonuses to the company in the event of reaching performance targets. According to Armstrong \& Brown (2009), the practice of evaluation and awards is a little-known point, despite being critical for several companies that have a reward system. This is also highlighted by Safari (2016), for whom the payment of rewards linked to the measurement system is essential. Additionally, the fact that there is no evaluation connected to an award system reduces the likelihood of positively influencing employee behavior, as proposed by Franco-Santos et al. (2007).

The most relevant point relating to the evaluation of results concerns the comparison of the planned goals with the performance for each indicator. Figure 5 presents the analysis of results for the Perfect Delivery indicator (document D005).

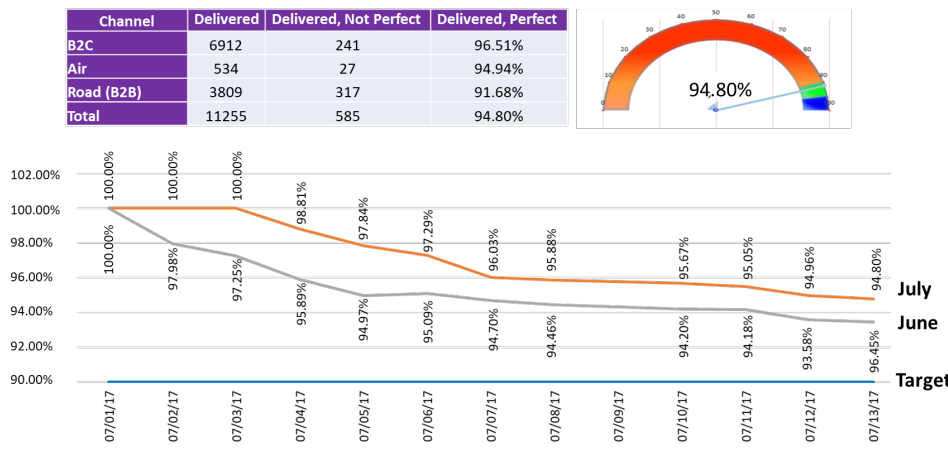

Figure 5. Analysis of results for the Perfect Delivery indicator. Source: document D005.

As can be seen, the graph presents the target (represented by the blue line, with a $90 \%$ rate of perfect deliveries), as well as the daily performance of the current month (July, orange curve) and the previous month (June, gray line), for the purpose of comparing results for similar days and weeks in subsequent months. One can see that the performance of the Perfect Deliveries indicator for the current month (July), in the period under analysis - day 1 to day 13 - not only exceeds the daily goal established, but is also higher than the previous month when the target had also been achieved.

This suggests that the continuous monitoring of indicators facilitates the achievement of goals by providing managers and employees with the ability to take measures to reverse deviations. This is exemplified in the statement given by Operations Foreman B: "They [indicators] allow us to keep track of the goals achieving and direct more energy to the critical points of the operation." 
According to the participant observation, although the goals have been consistently achieved, there is an analysis of the reasons that led to Non-Perfect Deliveries, with the aim of identifying sensitive points to management and for which action plans for improvement are prepared.

Figure 6 presents another example of analysis, now for the productivity/efficiency indicator.

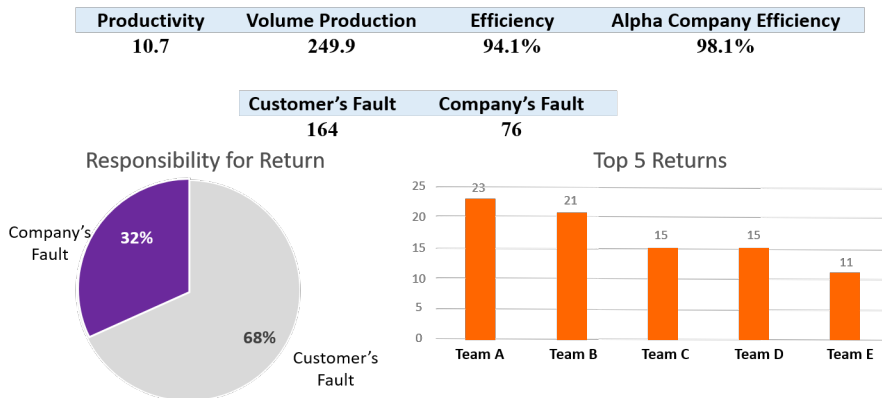

Figure 6. Analysis of results for the Productivity/Efficiency indicator of Alpha Company at the Fortaleza branch. Source: document D005.

In this analysis, it should be noted that there is a verification of the responsibilities for returns so that action plans and performance can be carried out, even if the indicator shows a result higher than its target (namely, 94\%, as shown in Table 5).

A monthly consolidation of the indicators is also carried out, in which it is possible to verify the company's performance across Brazil when compared with the branch investigated in the case study, as shown in Figure 7.

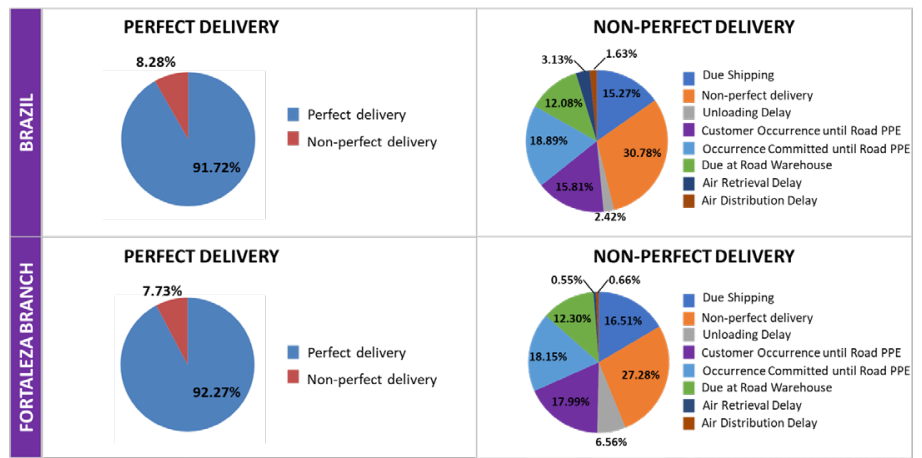

Figure 7. Report of the perfect delivery indicator. Source: Alpha Company database, document D003.

It is observed that both the Perfect Delivery indicator and the causes of the branch's Non-Perfect Delivery are compared with the company's national performance. Nevertheless, these comparisons can also occur for other performance criteria. Table 8 presents a "planned vs. accomplished" comparison for some of the main indicators to which this study had access. 
Table 8. Results of indicators provided by Alpha Company.

\begin{tabular}{|c|c|c|c|c|c|}
\hline No. & Indicator & Unit & Goal & Result & Status \\
\hline 1 & Effectiveness & $\%$ & $97.00 \%$ & $98.67 \%$ & Positive \\
\hline 2 & $\begin{array}{l}\text { Perfect Delivery, } \\
\text { Logistic Service Level } \\
\text { (road) }\end{array}$ & $\%$ & $90.00 \%$ & $94.80 \%$ & Positive \\
\hline 3 & $\begin{array}{l}\text { Perfect Delivery, } \\
\text { Logistic Service Level } \\
\text { (air) }\end{array}$ & $\%$ & $94.00 \%$ & $94.94 \%$ & Positive \\
\hline 4 & Scan compliance VAN & $\%$ & $96.00 \%$ & $97.90 \%$ & Positive \\
\hline 5 & $\begin{array}{l}\text { Scan compliance SIP / } \\
\text { HIP }\end{array}$ & $\%$ & $96 \% / 65 \%$ & $97.7 \% / 98.4 \%$ & Positive \\
\hline 6 & $\begin{array}{l}\text { Scan compliance SOP } \\
\text { / HOP }\end{array}$ & $\%$ & $96 \% / 65 \%$ & $\begin{array}{l}98.61 \% / \\
91.90 \%\end{array}$ & Positive \\
\hline 7 & POD Scan X Goal & $\%$ & $90.00 \%$ & $79.81 \%$ & Negative \\
\hline 8 & Requests & Hours & 4 & 7 & Negative \\
\hline 9 & Claims & Hours & 16 & 23 & Negative \\
\hline 10 & $\begin{array}{l}\text { Open CTRCs (+7 } \\
\text { days) }\end{array}$ & $\%$ & $10 \%$ & $8 \%$ & Positive \\
\hline 11 & $\begin{array}{l}\text { General open CTRCs } \\
\text { (Total Merchandise) }\end{array}$ & $\mathrm{R} \$$ & No goal & $3,326,791.19$ & - \\
\hline 13 & Productivity / Efficiency & $\%$ & $94.00 \%$ & $98.1 \%$ & Positive \\
\hline 14 & Air Export Freight & $\%$ & $30.00 \%$ & $24.33 \%$ & Negative \\
\hline 17 & Cost per volume (road) & $\mathrm{R} \$$ & $\mathrm{R} \$ 1.92$ & 4.03 & Negative \\
\hline 19 & Average cost per km & $\mathrm{R} \$$ & $\mathrm{R} \$ 3.76$ & 2.06 & Positive \\
\hline 24 & $\begin{array}{l}\% \text { Electronic Bill of } \\
\text { Lading scanned }\end{array}$ & $\%$ & $88.96 \%$ & $89 \%$ & Positive \\
\hline 25 & $\begin{array}{l}\text { Scan time - CAP (up to } \\
2 \text { days after delivery) }\end{array}$ & $\%$ & $90.00 \%$ & $92 \%$ & Negative \\
\hline
\end{tabular}

Among the 17 indicators listed, only one does not have an established target (indicator 11). Of the others, ten presented positive performance, in accordance with the planned targets. Considering that the analysis of the results is carried out systematically, using a standardized and indicator-based presentation, whose results are performing above the expected goals, there is a hypothesis of a positive relationship between the performance measurement process and the aggregate result of the studied company. An important step, however, is to formalize this evaluation procedure in the indicators manual, as well as connecting the results to the awards, as suggested in the literature.

Regarding the systematic review of the PMS, the fifth and last process proposed by Franco-Santos et al. (2007), it appears that the goals are reviewed annually, at a time close to the closing of the fiscal year by the company's headquarters. For the case of the $\mathrm{B} 2 \mathrm{C}$ service, according to the Operations Supervisor E, this is done according to the start / renewal of contracts:

The customer always reviews the goals at the end of a contract. So, if a 3- or 4year service contract is established with a set of goals, at the end of this contract, the board meets and reviews the goals and indicators in order to align with the changes proposed by the customer. 
Thus, in relation to the review of the system, it appears that the company does not have an established process for reviewing its indicators, but rather the targets of these indicators. Furthermore, the systematic review process must advocate the assessment of the system's consistency. It should be assessed whether the information contained in the measurement system is adding to the company's management, which was not verified.

There was no analysis of the indicators (if they still reflect the organization's goals), which can lead to obsolescence of the measurement system. In other words, there was no fundamental requirement, which is the ability to update the system, as noted by Vitaleet al. (1994).

Finally, the fact that there is no review indicates the poor capacity of the system to provide learning and improvement, as proposed by Franco-Santos et al. (2007). This appears contradictory, as there are meetings to assess and discuss the results. What is being questioned is, in fact, the extent to which the discussions are guided on indicators that reflect the company's objectives and whether such indicators could be institutionalized in performance improvement cycles. When reviewing only the targets of the indicators, the PMS's ability to provide learning and improvement is greatly inhibited.

\subsection{Summary of the case study}

Table 9 presents a summary of the case study, showing the characteristics, roles and processes identified at Alpha Company according to Franco-Santos et al. (2007).

Table 9. Use of indicators in the operations management of Alpha Company.

\begin{tabular}{|c|c|}
\hline Item & Analysis Summary \\
\hline \multicolumn{2}{|l|}{ Characteristics } \\
\hline $\begin{array}{l}\text { (i) Having performance } \\
\text { indicators }\end{array}$ & Identified. The company has 31 indicators. \\
\hline $\begin{array}{l}\text { (ii) Having an established } \\
\text { support infrastructure }\end{array}$ & $\begin{array}{l}\text { Identified. The company has its own system, which automatically } \\
\text { extracts indicators. }\end{array}$ \\
\hline \multicolumn{2}{|l|}{ Roles } \\
\hline $\begin{array}{l}\text { (i) Measuring } \\
\text { performance }\end{array}$ & Identified. Indicators are the basis for managing operations. \\
\hline (ii) Managing the strategy & $\begin{array}{l}\text { Partially identified. There is evidence of indicators being used at the } \\
\text { operation level. It was not possible to verify whether, and how, it } \\
\text { contributes to the achievement of the company's strategic vision. }\end{array}$ \\
\hline $\begin{array}{l}\text { (iii) Communicating } \\
\text { results }\end{array}$ & $\begin{array}{l}\text { Partially identified. No external communication (to customers) was } \\
\text { found. }\end{array}$ \\
\hline (iv) Influencing behavior & $\begin{array}{l}\text { Partially identified. No guidelines were found for a system of } \\
\text { rewards / compensation that creates a challenging environment and } \\
\text { increases productivity. }\end{array}$ \\
\hline $\begin{array}{l}\text { (v) Provide learning and } \\
\text { improvement }\end{array}$ & $\begin{array}{l}\text { Partially identified. No planning was found to manage the knowledge } \\
\text { generated or to institutionalize it for the company. }\end{array}$ \\
\hline \multicolumn{2}{|l|}{ Processes } \\
\hline $\begin{array}{l}\text { (i) Defining and selecting } \\
\text { indicators }\end{array}$ & $\begin{array}{l}\text { Partially identified. There is no manual of indicators with key } \\
\text { information for use. }\end{array}$ \\
\hline $\begin{array}{l}\text { (ii) Collecting and } \\
\text { processing data }\end{array}$ & $\begin{array}{l}\text { Partially identified. Although the indicators are extracted } \\
\text { automatically, there is no manual of indicators with key information } \\
\text { for use. }\end{array}$ \\
\hline
\end{tabular}


Table 9. Continued...

\begin{tabular}{ll}
\multicolumn{1}{c}{ Item } & \multicolumn{1}{c}{ Analysis Summary } \\
\hline (iii) Managing information & $\begin{array}{l}\text { Identified. The results are disseminated to the different levels of } \\
\text { performance in different forms of presentation, adapted to each } \\
\text { target audience. }\end{array}$ \\
\hline $\begin{array}{l}\text { (iv) Evaluating and } \\
\text { rewarding }\end{array}$ & $\begin{array}{l}\text { Partially identified. The company only gives the target of the } \\
\text { indicators, but not what should be done when good or bad } \\
\text { performance is verified. }\end{array}$ \\
\hline (v) Reviewing the system & $\begin{array}{l}\text { Not identified. The company does not review the indicators (only its } \\
\text { targets), nor does it review the measurement system itself. }\end{array}$ \\
\end{tabular}

It is observed that the use of indicators is part of the routine of the Alpha Company. Nevertheless, the process of use is not clear or structured. Indicators may be used according to the experience and the individual knowledge of each user, which can generate deviations in their interpretation. This is already highlighted by the literature as a barrier to obtaining good results in a performance measurement system (Flapper et al., 2006).

Furthermore, the existence of indicators may cause undesirable and unintended consequences (Franco-Santos \& Otley, 2018) that were or were not planned, which invariably influences the behavior of employees. Consideration should be given to how the system can be used to manage relationships and how to reward people appropriately. Without this role, employees may focus on producing a good indicator (means), instead of generating value for the company (end) (Sink \& Tuttle, 1993), which appears to be taking place in the company, according to the interviews carried out.

Finally, the poor capacity to update the system stands out, as the systematic review process is virtually non-existent, being restricted to the review of goals, which does not support learning and continuous improvement.

\section{Conclusion}

This article aimed to assess the performance measurement process in operations management in 3PL Providers. For doing so, a case study was carried out in a multinational 3PL Provider with a branch in Fortaleza, in the state of Ceará, Brazil. Six in-depth interviews were conducted and triangulated with secondary data from seven types of documents as well as participant observations.

Regarding the first specific objective of the study, the indicators used by the company were characterized. From the perception of the interviewees, it was possible to evaluate the importance of using performance indicators, as well as their insertion in the company's operational routine. Based on this analysis, it was concluded that the company has a well-balanced set of indicators that is consistent with the indicators in the sector-specific literature.

In spite of such importance, it was also found that not all of the employees were aware of the meanings and the correct way to measure performance indicators, which was evidenced both in the interviews and in the observations. This weakness can affect the company's performance, as the correct use of indicators helps to direct operations towards the achievement of strategic objectives.

After characterizing indicators, the performance measurement process was described, according to the second specific objective. The findings show that the company does not satisfactorily perform all measurement processes considered in the 
reviewed literature. In this regard, there was no evidence of any structure in the company supporting the selection and definition of indicators, as well as their use. Moreover, there was no systematic review process, which weakens the PMS by failing to prevent it from becoming obsolete.

The study was able to analyze how the performance measurement and management process occurs in 3PL Providers, answering its research question and reaching its main objective. Thus, considering the interviews that pointed to the insertion of the indicators in the company's routine, the documents provided and analyzed, the participation in a follow-up meeting, and the several indicators performing above target, it was concluded that the PMS and its indicators assist in the management of the $3 \mathrm{PL}$ Provider's operations studied and contribute to the achievement of organizational goals. Nevertheless, a measurement system that has not been properly structured may generate misinterpretation and management failures, as it is highly centered on the individual experience of employees, as opposed to a formal and structured process, which can be substantially improved with the formalization of a manual of indicators.

The findings also show that not all employees understand or know how to obtain improvements from the information provided by the PMS indicators. Thus, it would be appropriate to adopt a model for defining the indicators based on Neely et al. (1997) and hold a workshop with employees to discuss them, which could contribute to allowing greater gains for the company and its customers. This can be addressed in future research, through more interventionist approach, such as Action Research.

Also, in this context, a thorough investigation of the main variables measured, the way they are handled for the construction of indicators and the relationship between these indicators and organizational goals could bring important insights both to the performance management literature and managerial practice. In this sense, it should be noted that such an approach would allow analyzing - and, perhaps, testing - the possible causal relationship between the system of indicators and the results obtained by the organization, a limitation that the scope of this study did not address.

Finally, evidence shows an incipient structuring for performance evaluation, which is in line with the specific literature of the logistics sector (Beaulieu et al., 2018; Zago et al., 2008, p. 191). Such conclusions are not only of interest to the company studied. In fact, they also contribute to other companies in the identification of gaps in their performance measurement processes and systems. In addition, they provide guidelines for future research on subjects such as the systematization of the performance measurement process, the preparation and dissemination of indicator manuals for 3PL Providers, and an investigation of causal relationships between PMS and organizational goals.

The research findings presented here are not generalizable, which is a limitation inherent of any single-case study: they are not aimed at statistical generalizations or extrapolating results, as is the case in quantitative research. Case studies provide indepth knowledge of a particular phenomenon in order to understand it's the subjective aspects, as achieved with the study carried out.

\section{References}

Abidi, H., Dullaert, W., De Leeuw, S., Lysko, D., \& Klumpp, M. (2019). Strategic partner evaluation criteria for logistics service provider networks. International Journal of Logistics Management, 30(2), 438-466. http://dx.doi.org/10.1108/IJLM-07-2017-0178. 
Abijaude, J. A., Mano, A. P., Silva, W. V., \& Fettermann, D. C. (2016). Análise dos indicadores de desempenho de um centro de distribuição de bebidas. Engevista, 18(1), 125-141. http://dx.doi.org/10.22409/engevista.v18i1.705.

Araújo, P. C. D., Maduro, M. R., Zogahib, A. L., Lima, O. P., \& Silva, L. C. D. J. (2015). Indicadores de desempenho em operações, logística e cadeia de suprimentos numa multinacional do polo industrial de Manaus. Gestão e Sociedade, 7(18), 326-342. http://dx.doi.org/10.21171/ges.v7i18.1932.

Armstrong, M., \& Brown, D. (2009). Increasing the effectiveness of reward management. In 2nd European Reward Management Conference (ERMC 2009). Brussels: EIASM.

Ballou, R. H. (2006). Gerenciamento da cadeia de suprimentos/logísita empresarial (5th ed.). Porto Alegre: Bookman.

Barbosa, L. (2008). O estudo de caso e a evolução da pesquisa em administração: limitações do método ou dos pesquisadores? In Anais do XXXII Encontro Nacional dos Programas de Pós-graduação e Pesquisa em Administração. Rio de Janeiro: ANPAD.

Beaulieu, M., Roy, J., \& Landry, S. (2018). Logistics outsourcing in the healthcare sector: lessons from a Canadian experience. Canadian Journal of Administrative Sciences, 35(4), 635-648. http://dx.doi.org/10.1002/cjas.1469.

Belmonte, E. C. M., \& Botter, D. A. (2015). Uma proposta de indicadores logísticos voltados para a indústria. Revista Techoje.

Bititci, U., Garengo, P., Dörfler, V., \& Nudurupati, S. (2012). Performance measurement: challenges for tomorrow. International Journal of Management Reviews, 14(3), 305-327. http://dx.doi.org/10.1111/j.1468-2370.2011.00318.x.

Bolumole, Y. A. (2003). Evaluating the supply chain role of logistics service providers. International Journal of Logistics Management, 14(2), 93-107. http://dx.doi.org/10.1108/09574090310806620.

Bowersox, D. J., Closs, D. J., Cooper, M. B., \& Bowersox, J. C. (2016). Gestão logística da cadeia de suprimentos (4. ed.). Porto Alegre: AMGH.

Cândido, L. F., Lima, S. H. O., \& Barros, J. P., No. (2016). Análise de sistemas de medição de desempenho na indústria da construção. Ambiente Construído, 16(2), 189-208. http://dx.doi.org/10.1590/s1678-86212016000200087.

Cellard, A. (2010). A análise documental. In J. Poupart, J. P. Deslauriers, L. H. Groulx, A. Laperrière, R. Mayer, A. P. Pires, M. Jaccoud, A. Cellard, G. Houle \& A. Giorgi (Eds.), A pesquisa qualitativa: enfoques epistemológicos e metodológicos (pp. 295-316). Petrópolis: Vozes.

Chaves, R. P., \& Callado, A. A. C. (2014). Análise das relações entre o grau de complexidade das estruturas das cadeias de suprimento e o uso de indicadores de desempenho. The Journal of American Science, 20(1), 80-105. http://dx.doi.org/10.5020/23180722.2014.v20n1p80.

Chen, K., \& Wu, W. (2011). Applying analytic network process in logistics service provider selection - a case study of the industry investing in southeast ASIA. International Journal of Electronic Business Management, 9(1), 24-36.

Chizzoti, A. (2011). Pesquisa qualitativa em ciências humanas e sociais (6. ed.). Petrópolis: Vozes.

Choong, K. K. (2013). Understanding the features of performance measurement system: a literature review. Measuring Business Excellence, 17(4), 102-121. http://dx.doi.org/10.1108/MBE-05-2012-0031.

Chopra, S., \& Meindl, P. (2016). Gestão da cadeia de suprimentos: estratégia, planejamento e operações (6. ed.). São Paulo: Pearson Education do Brasil.

Collis, J., \& Hussey, R. (2005). Pesquisa em administração: um guia prático para alunos de graduação e pós-graduaçao (2. ed.). Porto Alegre: Bookman. 
Conceição, S. V., \& Quintão, R. T. (2004). Avaliação do desenpenho logístico da cadeia brasileira de suprimentos de refrigerantes. Gestão \& Produção, 11(3), 441-453. http://dx.doi.org/10.1590/S0104-530X2004000300015.

Cooper, D. R., \& Schindler, P. S. (2016). Métodos de pesquisa em administração (12. ed.). Porto Alegre: AMGH.

Creswell, J. W. (2007). Projeto de pesquisa: métodos qualitativo, quantitativo e misto (2. ed.). Porto Alegre: Artmed.

Fernandez, A. M. P., Vanti, A. A., Andrade, R. A. E., \& Gómez, J. M. (2008). Proposta de um modelo de medição de desempenho logístico apoiado pela lógica difusa: o caso de uma indústria de motores. Revista Íberica de Sistemas e Tecnologias de Informação, 2(12), 5364.

Flapper, S. D. F., Fortuin, L., \& Stoop, P. P. M. (2006). Towards consistent performance management system. International Journal of Operations \& Production Management, 16(7), 27-37. http://dx.doi.org/10.1108/01443579610119144.

Franco-Santos, M., \& Otley, D. (2018). Reviewing and theorizing the unintended consequences of performance management systems. International Journal of Management Reviews, 20(3), 696-730. http://dx.doi.org/10.1111/ijmr.12183.

Franco-Santos, M., Kennerley, M., Micheli, P., Martinez, V., Mason, S., Marr, B., Gray, D., \& Neely, A. (2007). Towards a definition of a business performance measurement system. International Journal of Operations \& Production Management, 27(8), 784-801. http://dx.doi.org/10.1108/01443570710763778.

Franco-Santos, M., Lucianetti, L., \& Bourne, M. (2012). Contemporary performance measurement systems: a review of their consequences and a framework for research. Management Accounting Research, 23(2), 79-119. http://dx.doi.org/10.1016/j.mar.2012.04.001.

Gibbs, G. (2009). Análise de dados qualitativos. Porto Alegre: Artmed.

Gray, D. E. (2012). Pesquisa no mundo real (2. ed.). Porto Alegre: Penso.

Järvinen, J., \& Karjaluoto, H. (2015). The use of web analytics for digital marketing performance measurement. Industrial Marketing Management, 50, 117-127. http://dx.doi.org/10.1016/j.indmarman.2015.04.009.

Kaplan, R. S., \& Norton, D. P. (1996). Using the balanced scorecard as a strategic management system. Harvard Business Review, 74(1), 75-85.

Kaplan, R. S., \& Norton, D. P. (1992). The balanced scorecard: measures that drive performance. Harvard Business Review, 70(1), 71-79. PMid:10119714.

Kennerley, M., \& Neely, A. (2002). A framework of the factors affecting the evolution of performance measurement systems. International Journal of Operations \& Production Management, 22(11), 1222-1245. http://dx.doi.org/10.1108/01443570210450293.

Labuschagne, A. (2003). The qualitative report qualitative research: airy fairy or fundamental? Qualitative Report, 8(1), 100-103.

Lampreia, J., \& Major, M. J. (2017). A behavioural perspective on the effects of using performance measurement systems in the companies: evidence from a case study. Dos Algarves: A Multidisciplinary e-Journal, 29, 83-101. http://dx.doi.org/10.18089/DAMeJ.2017.29.5.

Longaray, A. A., Munhoz, P. R., \& Tavares, K. S. (2015). Análise do nível de utilização de Indicadores de Desempenho Logístico: um estudo de caso no cluster portuário-marítimo de Rio Grande. Exacta, 13(1), 67-79. http://dx.doi.org/10.5585/exactaep.v13n1.5379.

Luna, M. M. M. (2001). O processo de terceirização das atividades logísticas. In Anais do IX Simpósio de Administração da Produção, Logística e Operações Internacionais. São Paulo: FGV-EAESP. 
Medori, D., \& Steeple, D. (2000). A framework for auditing and enhancing performance measurement systems. International Journal of Operations \& Production Management, 20(5), 520-533. http://dx.doi.org/10.1108/01443570010318896.

Neely, A., \& Bourne, M. (2000). Why measurement initiatives fail. Measuring Business Excellence, 4(4), 3-7. http://dx.doi.org/10.1108/13683040010362283.

Neely, A., Gregory, M., \& Platts, K. (1995). Performance measuremente system design: a literature review and research agenda. International Journal of Operations \& Production Management, 15(4), 80-116. http://dx.doi.org/10.1108/01443579510083622.

Neely, A., Mills, J., Platts, K., Richards, H., Gregory, M., Bourne, M., \& Kennerley, M. (2000). Performance measurement system design: developing and testing a process-based approach. International Journal of Operations \& Production Management, 20(10), 11191145. http://dx.doi.org/10.1108/01443570010343708.

Neely, A., Richards, H., Mills, J., Platts, K., \& Bourne, M. (1997). Designing performance measures: a structured approach. International Journal of Operations \& Production Management, 17(11), 1131-1152. http://dx.doi.org/10.1108/01443579710177888.

Neves, M. A. O. (2009). Tudo sobre indicadores de desempenho em logística. Revista Mundo Logística, 12, 197-206.

Okwir, S., Nudurupati, S. S., Ginieis, M., \& Angelis, J. (2018). Performance measurement and management systems: a perspective from complexity theory. International Journal of Management Reviews, 20(3), 731-754. http://dx.doi.org/10.1111/ijmr.12184.

Oliveira, G. C., No., Silva, D., Costabile, L. T., \& Barros, E. (2013). Insucesso na terceirização do transporte de carga biológica para operador logístico: um estudo de caso no laboratório de análise biológica. In Anais do VIII Simpósio de Excelência em Gestão e Tecnologia (SEGeT) (pp. 95-114). Resende: AEDB.

Oliveira, G. C., No. (2008). Integração complexa entre empresa contratante e operador logístico: critérios para contratação (Dissertação de mestrado). Programa de Pósgraduação em Engenharia de Produção, Universidade Paulista, São Paulo.

Richardson, R. J. (2011). Pesquisa social: métodos e técnicas (3. ed.). São Paulo: Atlas.

Rocha, I., Beuren, I. M., \& Hein, N. (2012). Rentabilidade de empresas que utilizam o Balanced Scorecard (Bsc) versus empresas que utilizam somente indicadores de desempenho financeiros. Revista Eletrônica de Estratégia \& Negócios, 5(2), 88-119. http://dx.doi.org/10.19177/reen.v5e2201288-119.

Rodriguez, C. M. T., Luz, E. M., \& Schmitt, H. C., No. (2016). Uma proposta de avaliação do desempenho na logística internacional. In Anais do III Workshop de Comércio Exterior: Perspectivas para a Internacionalização de PMEs - Oportunidades e Desafios (pp. 1-11). Criciúma: UNESC.

Safari, A. (2016). A new quantitative-based performance management framework for service operations. Knowledge and Process Management, 23(4), 307-319. http://dx.doi.org/10.1002/kpm.1524.

Sainaghi, R., Phillips, P., \& Zavarrone, E. (2017). Performance measurement in tourism firms: a content analytical meta-approach. Tourism Management, 59, 36-56. http://dx.doi.org/10.1016/j.tourman.2016.07.002.

Santos, C. H. S., Vieira, G. B. B., \& Pasa, G. S. (2009). Avaliação de operadores logísticos: o caso dos vales do rio pardo e do rio Taquari no Rio Grande do Sul. In XI Simpósio de Administração da Produção, Logística e Operações Internacionais (pp. 1-11). São Paulo: FGV-EAESP.

Schwartz, R., \& Deber, R. (2016). The performance measurement-management divide in public health. Health Policy, 120(3), 273-280. http://dx.doi.org/10.1016/j.healthpol.2016.02.003. PMid:26897247. 
Sink, D. S., \& Tuttle, T. C. (1993). Planejamento e medição para performance. Rio de Janeiro: Qualitymark.

Sousa, D. S. V., Cândido, L. F., \& Barros, J. D. P., No. (2018). Medição de desempenho na construção civil: um estudo exploratório com construtoras cearenses. Ambiente Construído, 18(1), 9-29. http://dx.doi.org/10.1590/s1678-86212018000100207.

Teixeira, J. C., \& Nascimento, R. (2011). Triangulação entre métodos na administração: gerando conversações paradigmáticas ou meras validações convergentes? In Anais do XXXV Encontro Nacional dos Programas de Pós-Graduação e Pesquisa em Administração. Rio de Janeiro: ANPAD.

Toni, A., \& Tonchia, S. (2001). Performance measurement systems: models, characteristics and measures. International Journal of Operations \& Production Management, 21(1-2), 4670. http://dx.doi.org/10.1108/01443570110358459.

Vieira, J. G., Carvalho, C. D., \& Yoshizaki, H. Y. (2016). Atributos da distribuição de carga e indicadores de desempenho logístico: pesquisa com empresas que atuam na região metropolitana de São Paulo. Transportes, 24(4), 10. http://dx.doi.org/10.14295/transportes.v24i4.912.

Vitale, M., Mavrinac, S. C., \& Hauser, M. (1994). Process/financial scorecard: a strategic performance measurement system. Planning Review, 22(12), 12-44.

Yin, R. K. (2010). Estudo de caso: planejamento e métodos (4. ed.). Porto Alegre: Bookman.

Zacharia, Z. G., Sanders, N. R., \& Nix, N. W. (2011). The emerging role of the third-party logistics provider (3PL) as an orchestrator. Journal of Business Logistics, 32(1), 40-54. http://dx.doi.org/10.1111/j.2158-1592.2011.01004.x.

Zago, C. A., Rigoni, J., Abreu, L. F., \& Rodriguez, C. M. T. (2008). Perspectivas metodológicas de avaliação de desempenho organizacional: aplicabilidade na logística. Revista Eletrônica Sistema \& Gestão, 3(3), 178-195.

Zamcopé, F. C., Ensslin, L., Ensslin, S. R., \& Dutra, A. (2010). Modelo para avaliar o desempenho de operadores logísticos: um estudo de caso na indústria têxtil. Gestão \& Produção, 17(4), 693-705. http://dx.doi.org/10.1590/S0104-530X2010000400005. 